\title{
LOYALITAS PELANGGAN TOKO AGNA JAYA PASAR LEGI DITINJAU DARI PELAYANAN, KETERIKATAN EMOSIONAL DAN GETHOK TULAR
}

\author{
Yusuf Roni, Supawi Pawenang, Ratna Damayanti \\ Program Studi Manajemen, Fakultas Ekonomi, Universitas Islam Batik Surakarta \\ Jl. KH. Agus Salim No. 10, 0271-714751 Surakarta \\ e-mail: yusufronii@gmail.com
}

\begin{abstract}
Customer loyalty is the state of the customer begins to have a positive attitude to a brand, so that it raises a commitment to brand, and intends to make a repeat purchase in the future. This study aims to determine the effect of service, emotional attachment and gethok tular on customer loyalty in Agna Jaya stores both partially and simultaneously. The population of this study is traditional market trades who are customers of Agna Jaya stores and take a sample of 40 respondents. The analysis technique in this study uses the method of multiple linear regresion analysis. The results showed that service, emotional attachment and gethok tular simultaneously influence customer loyalty. Partially service, emotional attachment and gethok tular have a significant effect on customer loyalty.
\end{abstract}

Keywords: Customer loyalty, service, emotional attachment, gethok tular

\section{LATAR BELAKANG}

Strategi pemasaran mempunyai peranan yang sangat penting untuk keberhasilan perusahaan umumnya dan pada bidang pemasaran khususnya (Lubis, 2004). Strategi pemasaran harus ditinjau dan dikembangkan sesuai dengan perkembangan pasar dan lingkungan pasar tersebut. Dengan demikian strategi pemasaran harus dapat memberikan gambaran yang jelas dan terarah tentang apa yang dilakukan perusahaan dalam menggunakan setiap kesempatan pada beberapa pasaran pasar. Dalam kegiatan jual-beli, erat kaitannya dengan loyalitas. Loyalitas merupakan aspek yang menjadi tolak ukur pembelian ulang. Kegiatan pembelian ulang akan muncul apabila konsumen puas terhadap produk yang dibeli, yang dapat menimbulkan sikap setia. Sikap setia dapat terwujud dalam respon positif terhadap merk tertentu, mempunyai komitmen dan memiliki niat untuk melakukan pembelian produk tertentu di masa depan.

Pelayanan adalah setiap kegiatan atau tindakan yang ditawarkan oleh satu pihak kepada pihak yang lain, pada dasarnya tidak berwujud dan tidak mengakibatkan kepemilikan apapun (Kotler, 2000). Sama halnya dengan sales penjualan barang yang selalu berusaha untuk menciptakan kepuasan konsumen. Menciptakan kepuasan pada konsumen dilakukan beberapa sales dengan cara memenuhi kebutuhan, keinginan, dan harapan dari pelanggan. Selain itu juga dapat dilakukan dengan cara memberi pelayanan penuh atas pelanggan. Dengan terciptanya kepuasan konsumen dapat memberikan manfaat, diantaranya hubungan antara perusahaan dan pelanggannya menjadi harmonis, memberikan dasar yang baik bagi pembelian ulang, terciptanya loyalitas konsumen. Mempertahankan semua konsumen akan lebih menguntungkan daripada dengan pergantian konsumen karena biaya untuk menarik pelanggan baru bisa lebih besar dari biaya mempertahankan konsumen yang sudah ada. 
Keterikatan merupakan suatu kondisi emosional pada hubungan khusus antara seseorang dan obyek tertentu. Berlaku pada keterikatan emosional konsumen pada suatu merk (Sukoco, 2011). Dalam membentuk keterikatan emosional, para pedagang pasar akan merasa lebih aman dan terjamin akan kualitas produk yang akan dibeli. Keterikatan ini akan terbentuk dengan sendirinya setelah transaksi yang terus terulang dalam kurun waktu yang cukup lama. Oleh karena itu, keterikatan emosional ini tidak akan muncul jika pembeli tidak merasakan puas atas pelayanan. Keterikatan ini juga menimbulkan sikap positif pembeli kepada pedagang dalam menawar harga ataupun kegiatan pembelian.

Gethok tular yang positif sangat dibutuhkan dalam mencukupi dan menggenapi poin-poin strategi pemasaran yang efektif dan efisien. Kemunculan gethok tular ini sangat diharapkan dapat terjadi, karena dari gethok tular yang positif akan memunculkan keuntungan yang cukup memuaskan atau menguntungkan. Dalam mengatasi persaingan yang sangat ketat, gethok tular merupakan salah satu tingkah laku pembeli yang loyal dan sangat menguntungkan bagi pedagang. Fenomena gethok tular dipercaya dapat memprovokasi pembeli untuk melakukan pembelian ulang, bisa mempengaruhi komunitas yang diikuti pelanggan, dan sangat efissien karena tidak mengeluarkan biaya yang besar.

Toko Agna Jaya bertempat di pasar legi surakarta memiliki 3 orang karyawan. Untuk pengiriman toko agna jaya memiliki 1 orang karyawan. Salah satu pelayanan di Toko Agna Jaya adalah pengiriman yang tidak dikenai biaya. Beberapa produk yang di jual toko Agna Jaya antara lain yaitu: bawang putih, bawang merah, bawang merah, bawang bombay, kacang tanah import, kacang tanah lokal, lada, ketumbar, kemiri, ebi/udang kering. Selain itu, Toko Agna Jaya juga memberikan bingkisan hari raya kepada setiap pelanggannya. Dari hal tersebut peneliti tertarik untuk meneliti "Loyalitas Pelanggan Di Toko Agna Jaya Pasar Legi Ditinjau Dari Pelayanan, Keterikatan Emosional, dan Gethok Tular".

\section{KAJIAN TEORITIS}

\section{Loyalitas Pelanggan}

Loyalitas pelanggan menurut Mowen dan Minor (2005) merupakan keadaan disaat pelanggan mulai memiliki sikap positif kepada suatu merek, sehingga memunculkan komitmen pada suatu merek, dan berniat untuk melakukan pembelian ulang dimasa mendatang. Loyalitas dapat disimpulkan sebagai suatu konsep attau pemikiran yang memusatkan pada rangkaian pembelian. Loyalitas selalu berhubungan dengan pilihan pelanggan dan pembelian konkret. Konsep dasar dari loyalitas adalah melalui pendekatan atittudinal dan pendekatan behavioural. Menurut Soegoto (2013) aspek-aspek yang dapat mempengaruhi loyalitas pelanggan antara lain: (1)kepuasan; (2)ikatan emosi; (3)kepercayaan; (4)pengalaman terhadap perusahaan; (5)kemudahan. Pelanggan yang memiliki loyalitas tinggi dapat terlihat dari beberapa karakteristik. Karakteristik tersebut antara lain: (1)sudah melaksanakan pembelian ulang dengan waktu yang teratur. (2)Membeli antar lini produk dan jasa; (3)Menyarankan kepada oranglain. (4)menunjukkan sikap penolakan terhadap merek lain.

\section{Pelayanan}

Menurut Kotler (2000), pelayanan adalah setiap kegiatan atau tindakan yang ditawarkan oleh satu pihak kepada pihak yang lain, pada dasarnya tidak berwujud dan tidak mengakibatkan kepemilikan apapun. Menurut Payne (2000), pelayanan adalah rasa menyenangkan atau tidak menyenangkan yang penerima pelayanan pada saat memperoleh 
pelayanan. Menurut Panjaitan dan Yuliati (2016) tingkat pelayanan dapat di ukur dengan lima dimensi yaitu keandalan, jaminan, bukti fisik, empati, dan daya tanggap.

\section{Keterikatan Emosional}

Menurut Sukoco (2011) keterikatan merupakan suatu kondisi emosional pada hubungan khusus anatra seseorang dan obyek tertentu. Berlaku pada keterikatan emosional konsumen pada suatu merk. Keterikatan emosional memiliki pengaruh positif terhadap loyalitas konsumen. Keterikatan memiliki tingkatan yang bervariasi, dimana keterikatan yang tinggi diasosiasikan dengan perasaan yang kuat dari connection (koneksi), affection (afeksi), love (cinta), dan passion (gairah). Menurut Sukoco (2011) yang menyatakan bahwa emosional yng sudah terikat membuat seseorang selalu berupaya untuk mendekat dengan suatu objek dalam hal ini yaitu merk.

\section{Gethok Tular}

Menurut Praswati (2009) gethok tular merupakan komunikasi antar personal yang dapat dijadikan sumber terpercaya atau dapat diandalkan oleh pendengar informasi. Kebiasaan masyarakat Indonesia yang suka berkumpul akan mempercepat terciptanya gethok tular yang positif. Gethok tular lebih cepat diterima oleh pelanggan karena pelanggan biasanya mendapat informasi dari seseorang yang sudah dipercayai seperti saudara atau kawan. Ketika seseorang menerima rekomendasi suatu produk atau jasa dari oranglain, apabila rekomendasi bersifat positif maka seseorang akan tertarik untuk mencoba produk atau jasa yang ditawarkan.

\section{METODEi PENELITIANi}

Penelitian ini menggunakan metode kuantitatif deskriptif. Penelitian ini dilakukan di Toko Agna Jaya yang berada di Pasar Legi. Dalam penelitian ini waktu yang dibutuhkan kurang lebih selama dua bulan dimulai sejak 1 maret sampai 15 april 2020. Populasi yang diambil dalam penelitian ini adalah pedagang pasar tradisional di wilayah Surakarta dan Sukoharjo yang merupakan pelanggan dari Toko Agna Jaya Pasar Legi. Jumlah sampel yang diambil dalam penelitian ini sebanyak 40 orang. Sedangkan teknik sampling yang digunakan dalam penelitian ini menggunakan teknik purposive sampling.

\section{HASILi DAN PEMBAHASAN}

1) Uji Validitas

Tabel.1 Hasil Uji Validitas Variabel Loyalitas Pedagang

\begin{tabular}{lccl}
\hline Pernyataan & Total Person Correlation & R tabel & Keterangan \\
\hline Pernyataan 1 & 0,677 & 0,444 & Valid \\
Pernyataan 2 & 0,785 & 0,444 & Valid \\
Pernyataan 3 & 0,767 & 0,444 & Valid \\
Pernyataan 4 & 0,879 & 0,444 & Valid \\
\hline
\end{tabular}

Sumber : Data Primer Tahun 2020 
Tabel.2 Hasil Uji Validitas Variabel Pelayanan

\begin{tabular}{lcll}
\hline Pernyataan & Total Person Correlation & R tabel & Keterangan \\
\hline Pernyataan 1 & 0,822 & 0,444 & Valid \\
Pernyataan 2 & 0,651 & 0,444 & Valid \\
Pernyataan 3 & 0,714 & 0,444 & Valid \\
Pernyataan 4 & 0,746 & 0,444 & Valid \\
\hline
\end{tabular}

Sumber : Data Primer Tahun 2020

Tabel.3 Hasil Uji Validitas Variabel Keterikatan Emosional

\begin{tabular}{lcll}
\hline Pernyataan & Total Person Correlation & R tabel & Keterangan \\
\hline Pernyataan 1 & 0,606 & 0,444 & Valid \\
Pernyataan 2 & 0,937 & 0,444 & Valid \\
Pernyataan 3 & 0,727 & 0,444 & Valid \\
Pernyataan 4 & 0,857 & 0,444 & Valid \\
Pernyataan 5 & 0,681 & 0,444 & Valid
\end{tabular}

Sumber: Data Primer Tahun 2020

Tabel.4 Uji Validitas Variabel Gethok Tular

\begin{tabular}{lcll}
\hline Pernyataan & Total Person Correlation & R tabel & Keterangan \\
\hline Pernyataan 1 & 0,682 & 0,444 & Valid \\
Pernyataan 2 & 0,674 & 0,444 & Valid \\
Pernyataan 3 & 0,780 & 0,444 & Valid \\
Pernyataan 4 & 0,790 & 0,444 & Valid \\
Pernyataan 5 & 0,812 & 0,444 & Valid
\end{tabular}

Sumber : Data Primer Tahun 2020

Berdasar dari hasil uji validitas diatas, dapat diketahui bahwa 18 pernyataan yang diajukan kepada 20 responden dengan minimum nilai indeks validitas 0,444 sehingga semua item pernyataan dinyatakan valid karena $\mathrm{r}$ hitung $>\mathrm{r}$ tabel maka 20 pernyataan tersebut dapat digunakan sebagai kuesioner penelitian. 
2) Uji Realibilitas

Tabel.5 Hasil Uji Reliabilitas

\begin{tabular}{llll}
\hline Nama Variabel & $\begin{array}{l}\text { Cronbach } \\
\text { Alpha }\end{array}$ & $\begin{array}{l}\text { Kriteria } \\
\text { Nunnaly }\end{array}$ & Keterangan \\
\hline Loyalitas Pedagang & 0,779 & 0,60 & Reliabel \\
Pelayanan & 0,707 & 0,60 & Reliabel \\
Keterikatan Emosional & 0,829 & 0,60 & Reliabel \\
Gethok Tular & 0,799 & 0,60 & Reliabel \\
\hline
\end{tabular}

Sumber : Data Primer Tahun 2020

Dari hasil uji reabilitas diatas dapat disimpulkan bahwa seluruh item kuesioner mengenai variabel Pelayanan (X1), Keterikatan Emosional (X2), Gethok Tular (X3) dan Loyalitas Pedagang (Y) menunjukkan nilai yang reliabel.

3) Uji Asumsi Klasik

a. Uji Normalitas

Tabel.6 Hasil Uji Normalitas Kolmogorov Smirnov

\begin{tabular}{llll}
\hline Kolmogorov-Smirnov Z & Signifikansi & Batas & Keterangan \\
\hline 0,538 & 0,935 & 0,05 & Normal \\
\hline
\end{tabular}

Sumber : Data Primer diolah tahun 2020

Dari hasil pengujian normalitas kolmogorov smirnov diatas menunjukkan bahwa variabel dalam penelitian ini mempunyai nilai signifikansi lebih besar dari 0,05 pada $($ sig $>0,05)$, sehingga dapat disimpulkan data dalam penelitian ini berdistribusi normal.

\section{b. Uji Multikolinearitas}

Tabel. 7 Uji Multikolineritas

\begin{tabular}{llll}
\hline Variabel & Tolerance & VIF & Keterangan \\
\hline Pelayanan & 0,725 & 1,379 & Tidak terjadi multikolineritas \\
$\begin{array}{l}\text { Keterikatan } \\
\text { Emosional }\end{array}$ & 0,805 & 1,242 & Tidak terjadi multikolineritas \\
Gethok Tular & 0,863 & 1,159 & Tidak terjadi multikolineritas \\
\hline
\end{tabular}

Sumber : Data Primer 2020

Tabel uji multikolineritas diatas menunjukkan bahwa nilai tolerance lebih dari 0,1 dan nilai VIF tidak lebih dari 10, oleh karena itu dapat disimpulkan bahwa model regresi pada penelitian ini tidak terjadi multikolineritas. 


\section{c. Uji Heteroskedastisitas}

Tabel.8 Uji Heteroskedastisitas Glejser

\begin{tabular}{llll}
\hline Variabel & Signifikansi & Batas & Keterangan \\
\hline Pelayanan & 0,254 & $>0,05$ & $\begin{array}{l}\text { Tidak terjadi } \\
\text { heteroskedastisitas }\end{array}$ \\
$\begin{array}{l}\text { Keterikatan } \\
\begin{array}{l}\text { Emosional } \\
\text { Gethok Tular }\end{array}\end{array} 0,242$ & $>0,05$ & $\begin{array}{l}\text { Tidak terjadi } \\
\text { heteroskedastisitas }\end{array}$ \\
& 0,159 & $>0,05$ & $\begin{array}{l}\text { Tidak terjadi } \\
\text { heteroskedastisitas }\end{array}$ \\
\hline
\end{tabular}

Sumber : Data Primer 2020

Dari tabel diatas dapat diketahui bahwa variabel X1, X2, dan X3 yaitu pelayanan, keterikatan emosional dan gethok tular memperoleh nilai signifikansi yang lebih besar dari 0,05. Maka dapat disimpukan bahwa ketiga variabel dalam penelitian ini dapat dikatakan telah lolos uji heteroskedastisitas.

\section{4) Analisis Data}

\section{a. Regresi Linear Berganda}

Dari hasil analisis regresi dapat diketahu persamaan regresi berganda sebagai berikut:

$$
Y=-4,152+0,444 X_{1}+0,339 X_{2}+0,366 X_{3}
$$

Apabila variabel pelayanan meningkat satu satuan maka akan mengakibatkan peningkatan pada variabel loyalitas pedagang sebesar 0,444 satuan dan sebaliknya, apabila variabel pelayanan menurun satu atuan akan menurunkan loyalitas pedagang sebesar 0,444. Apabila variabel keterikatan emosional meningkat satu satuan maka akan mengakibatkan peningkatan pada variabel loyalitas pedagang sebesar 0,339 satuan dan sebaliknya, apabila variabel keterikatan emosional menurun satu atuan akan menurunkan loyalitas pedagang sebesar 0,339. Apabila variabel gethok tular meningkat satu satuan maka akan mengakibatkan peningkatan pada variabel loyalitas pedagang sebesar 0,366 satuan dan sebaliknya, apabila variabel gethok tular menurun satu atuan akan menurunkan loyalitas pedagang sebesar 0,366.

\section{b. Uji F}

\section{Tabel.9 Hasil Uji f}

\begin{tabular}{llllll}
\hline Model & F $_{\text {hitung }}$ & F $_{\text {tabel }}$ & Sig. & Std & Keterangan \\
\hline 1 & 30,141 & 2,84 & 0,000 & 0,05 & $\mathrm{H}_{0}$ ditolak \\
\hline
\end{tabular}

Sumber : Data Primer 2020

Dapat disimpulkan dari hasil olah data diatas, diketahui bahwa nilai f hitung sebesar $30,141>2,84$, dan nilai signifikansinya sebesar $0,000<0,05$. Dengan demikian berarti $\mathrm{H}_{0}$ ditolak, artinya variabel pelayanan, keterikatan emsoional dan Gethok Tular berpengaruh terhadap variabel loyalitas pedagang secara bersama-sama atau secara simultan dan signifikan. 
c. Uji t

Tabel.10 Hasil Uji t

\begin{tabular}{llllll}
\hline Variabel & $\mathbf{t}$ hitung & $\mathbf{t}$ tabel & Sig. & Std & Keterangan \\
\hline Pelayanan & 3,618 & 2,201 & 0,001 & $<0,05$ & Diterima \\
Keterikatan & 4,011 & 2,201 & 0,000 & $<0,05$ & Diterima \\
$\begin{array}{l}\text { Emosional } \\
\text { Gethok Tular }\end{array}$ & 3,720 & 2,201 & 0,001 & $<0,05$ & Diterima \\
\hline Sularima
\end{tabular}

Sumber : Data Primer 2020

Variabel kulitas produk memperoleh nilai t hitung $(3,618)>t$ tabel $(2,021)$ dengan nilai signifikansi sebesar $0,001<0,05$ berarti $\mathrm{H}_{0}$ ditolak. Kesimpulannya adalah variabel pelayanan memiliki pengaruh yang signifikan terhadap variabel loyalitas pelanggan. Variabel keterikatan emosional memperoleh nilai $t$ hitung $(4,011)>t$ tabel $(2,021)$ dengan nilai signifikansi sebesar $0,000<0,05$ berarti $\mathrm{H}_{0}$ ditolak. Kesimpulannya adalah variabel keterikatan emosional memiliki pengaruh yang positif dan signifikan terhadap variabel loyalitas pelanggan. Variabel Gethok Tular memperoleh nilai t hitung $(3,720)>\mathrm{t}$ tabel $(2,021)$ dengan nilai signifikansi sebesar $0,001<0,05$ berarti $\mathrm{H}_{0}$ ditolak. Kesimpulannya adalah variabel Gethok Tular memiliki pengaruh yang positif dan signifikan terhadap variabel loyalitas pelanggan.

d. Uji Koefisien Determinan $\left(\mathbf{R}^{\mathbf{2}}\right)$

Tabel.11 Hasil Analisis Koefisien Determinasi $\left(\mathbf{R}^{2}\right)$

\begin{tabular}{lll}
\hline Model & Adjust R Square & Keterangan \\
\hline 1 & 0,692 & Varibael independen \\
& & mampu menerangkan \\
& & variabel dependen \\
\hline
\end{tabular}

Sumber : Data Primer 2020

Berdasarkan hasil analisis koefisien determinasi diatas, nilai adjust $\mathrm{r}$ square sebesar 0,692 atau 69,2\%. Kesimpulannya adalah loyalitas pedagang dipengaruhi oleh variabel pelayanan, keterikatan emosional dan Gethok Tular sebesar 69,2\%. Sedangkan untuk pengaruh sebesar 30,8\% dipengaruhi oleh variabel yang lain diluar penelitian ini.

\section{PEMBAHASAN}

\section{Pengaruh Pelayanan, Keterikatan Emosional dan Gethok Tular Terhadap Loyalitas Pelanggan}

Hasil statistik menunjukkan perolehan nilai f hitung sebesar 30,141 dan nilai f tabel sebesar 2,84 dengan nilai signifikansi 0,000. Dapat dilihat nilai $\mathrm{f}$ hitung lebih besar dari nilai $\mathrm{f}$ tabel dan nilai signifikansi lebih kecil dari 0,05. Dengan demikian maka hasilnya adalah pelayanan, keterikatan emosional dan gethok tular berpengaruh secara simultan terhadap loyalitas pelanggan. Pelayanan, keterikatan emosional dan gethok tular adalah beberapa hal yang dapat mempengaruhi loyalitas pelanggan. Dalam penelitian ini dibuktikan dengan pengaruh sebesar 0,692 atau 69,2\% dan untuk 30,8\% dipengaruhi oleh beberapa hal yang tidak termasuk dalam penelitian ini. 


\section{Pengaruh Pelayanan Terhadap Loyalitas Pelanggan}

Hasil dari analisis statistik menunjukkan bahwa secara parsial pelayanan berpengaruh signifikan terhadap loyalitas pelanggan. Hal ini dibuktikan dengan nilai thitung sebesar 3,618 yang lebih besar daripada nilai t tabel yaitu sebesar 2,021, dengan signifikansi sebesar 0,001 yang lebih kecil dari 0,05. Dan nilai koefisien regresi pelayanan terhadap loyalitas pelanggan menunjukkan nilai 0,444. Hasil Penelitian sesuai dengan penelitian terdahulu oleh Pawitra dan Harsono (2013), yang memperoleh hasil kualitas pelayanan berpengaruh secara signifikan terhadap loyalitas pelanggan. Kesimpulannya adalah semakin tinggi kualitas layanan yang diberikan dari sebuah perusahaan maka akan semakin tinggi pula loyalitas yang didapat oleh perusahaan dari pelanggan.

\section{Pengaruh Keterikatan Emosional Terhadap Loyalitas Pelanggan}

Hasil dari analisis statistik memperoleh nilai t hitung sebesar 4,011 yang lebih besar daripada nilai t tabel sebesar 2,021 dengan nilai signifikansi 0,000 yang lebih kecil dari 0,05. Dan variabel keterikatan emosional mempunyai nilai koefisien regresi sebesar 0,339 terhadap loyalitas pelanggan. Oleh karena itu dapat disimpulkan bahwa keterikatan emosional mempunyai pengaruh yang signifikan terhadap loyalitas pedagang. Keterikatan emosional yang baik dapat menguntungkan perusahaan, karena dapat mengingkatkan loyalitas pelanggan. Sebaliknya keterikatan emosional yang tidak baik atau keterikatan emosional yang buruk akan merugikan perusahaan. Hasil ini mendukung penelutuan terdahulu dari Hartawan (2011), yang menyatakan bahwa keterikatan emosional berpengaruh positif dan signifikan. Keterikatan emosional menjadikan seseorang berupaya untuk selalu dekat dengan suatu obyek, konsumen yang terikat secara emosional akan memiliki komitmen yang tinggi yang diwujudkan dengan loyalitas terhadap suatu merk atau perusahaan.

\section{Pengaruh Gethok Tular Terhadap Loyalitas Pelanggan}

Hasil dari analisis statistik yang dihitung peneliti melalui aplikasi SPSS versi 21, variabel gethok tular memperoleh nilai thitung sebesar 3,720 yang lebih besar dari nilai t tabel sebesar 2,021, dengan nilai signifikansi 0,01 yang lebih kecil daripada 0,05 dan dengan nilai koefisien regresi sebesar 0,366. Artinya varibael gethok tular berpenagruh secara signifikan terhadap variabel loyalitas pelanggan. Dapat ditarik kesimpulan bahwa loyalitas pelanggan meningkat setelah mendapat informasi tentang produk toko Agna jaya dari orang-orang disekitar melalui informasi yang baik yang keluar dari mulut kemulut. Hasil dari penelitian ini mendukung penelitian sebelumnya, yaitu penelitian Saputra, Suryani dan Nurcahya (2014), dalam penelitiannya dijelaskan bahwa gethok tular berpenagruh signifikan terhadap loyalitas pelanggan. Promosi dan Rekomendasi yang baik akan mendorong loyalitas pelanggan, dengan memberikan informasi dan rekomendasi positif tentang toko Agna Jaya.

\section{KESIMPULAN DAN SARAN}

\section{Kesimpulan}

Pelayanan, Keterikatan Emosional dan gethok tular berpengaruh secara simultan terhadap loyalitas pelanggan. Dibuktikan dengan nilai f hitung yang lebih besar dibandingkan dengan nilai f tabel, dengan nilai signifikansi yang lebih kecil daripada 0,05. Pelayanan berpengaruh secara signifikan terhadap loyalitas pelanggan di toko Agna Jaya. Dibuktikan dengan nilai thitung yang yang lebih kecil dibanding dengan $t$ tabel, dengan nilai signifikansi yang lebih besar daripada 0,05. Pelayanan toko yang baik akan meningkatkan loyalitas pelanggan, 
semakin bagus pelayanan toko akan membuat loyalitas pelanggan menjadi semakin baik dan sebaliknya. Keterikatan Emosional berpengaruh secara signifikan terhadap loyalitas pelanggan di toko Agna Jaya. Dibuktikan dengan hasil statistik uji t variabel Keterikatan Emosional dengan memperoleh nilai t hitung yang lebih besar dibanding nilai $t$ tabel, dengan nilai signifikansi yang lebih kecil dari 0,05. Semakin baik Keterikatan Emosional perusahaan dengan pedagang akan menguntungkan perusahaan. Gethok tular berpengaruh secara signifikan terhadap loyalitas pelanggan di toko Agna Jaya. Dibuktikan dengan hasil statistik uji t memperoleh nilai t hitung yang lebih besar dibandingkan dengan nilai t tabel, dengan nilai signifikansi yang lebih kecil daripada 0,05. Iformasi, rekomendasi dan promosi yang dilakukan orang sekitar secara tidak sadar mampu meningkatkan loyalitas pedagang menjadi semakin loyal.

\section{Saran}

Pelanggan toko dari toko Agna Jaya yang sudah baik harus dijaga konsistensinya supaya konsumen tetap loyal. Pemasaran dari mulut ke mulut (gethok tular) dan keterikatan emosional juga sangat efektif untuk lebih diterapkan lebih baik lagi. Sedangkan untuk peneliti selanjutnya dapat mengembangkan penelitian ini dengan meneliti faktor-faktor lain yang dapat mempengaruhi loyalitas pelanggan, seperti contohnya factor budaya, social dan psikologis. Peneliti selanjutnya juga dapat meneliti dengan metode penelitian yang lain seperti metode wawancara yang lebih medalam supaya memperoleh informasi yang lebih jelas dan lebih bervariasi.

\section{DAFTAR PUSTAKA}

Hartawan, R. A. (2011). Pengaruh Pengalaman dan Keterikatan Emosional Pada Merk Terhadap Loyalitas Konsumen. Jurnal Manajemen Teori Dan Terapan, 4(3), 1-12.

Kotler, Philip dan A.B. Susanto. 2000. Manajemen Pemasaran di Indonesia: Analisis Perencanaan, Implementasi, dan Pengendalian. Jakarta: Salemba Empat.

Lubis, Arlina Nurbaity. (2004). Strategi Pemasaran dalam Persaingan Bisnis. Skripsi. Sumatera Utara: USU Digital Library

Mowen, J. C., \& Minor, M. (2005). Consumer Behaviour. Boston: Irwin

Panjaitan, J. E., \& Yulianti, A. L. (2016). Pengaruh Kualitas Pelanan Terhadap Kepuasan Pelanggan Pada JNE Cabang Bandung. DeReMa Jurnal Manajemen, 11(2), 265-289.

Pawitra, T. G., \& Harsono, S. (2013). Pengaruh Kualitas Layanan dan Kepuasan Emosional Terhadap Kualitas Hubungan dan Loyalitas Pelanggan KFC Di Surabaya. Journal Of Business Adn Banking, 3(1), 17-30.

Payne, Adrian. (2000). Pemasaran Jasa. (The Essence of Service Marketing). Terjemahan Fandy Tjiptono. Edisi Pertama. Yugyakarta: Penerbit Andi

Praswati, Aflit Nuryulia. (2009). Analisis Faktor-faktor yang Mempengaruhi Komunikasi Word of Mouth Terhadap Minat Guna Jasa Ulang (Studi Kasus pada PT. Nasmoco di Semarang). Tesis. Semarang: Universitas Diponegoro 
Saputra, I. B. I., Surani, A., \& Nurcahya, I. K. (2014). Pengaruh Relasi Konsumen dan Word Of Mouth Terhadap Loyalitas Nasabah Bank BPD Bali Cabang badung. 526-537.

Soegoto, A. S. (2013). Persepsi Nilai Dan Kepercayaan Terhadap Kepuasan Dan Dampaknya Terhadap Loyalitas Konsumen. Jurnal EMBA, 1(3), 1271-1283.

Sukoco, B.M. dan Hartawan, R.A. (2011). Pengaruh Pengalaman dan Keterikatan Emosional Pada Merk Terhadap Loyalitas Konsumen. Jurnal Manajemen Teori dan Terapan, 4(3), 1-12. 